\title{
Organic Agriculture, Greenhouse Gas Emissions and Environmental Efficiency: An Empirical Study on OECD Countries
}

\author{
Mariarosaria Agostino ${ }^{1}$ \\ ${ }^{1}$ Department of Economics, Statistics and Finance, University of Calabria, Italy \\ Correspondence: Mariarosaria Agostino, Department of Economics, Statistics and Finance, Cubo 1C, Ponte P. \\ Bucci, University of Calabria, Rende (CS), Italy. Tel. 39-0984-492-447. E-mail: m.agostino@unical.it
}

Received: July 27, 2016

Accepted:September 9, 2016

Online Published: October 25, 2016

doi:10.5539/ijef.v8n11p78

URL: http://dx.doi.org/10.5539/ijef.v8n11p78

\begin{abstract}
The impact of organic farming on greenhouse gas emissions is a much debated issue, which has been predominantly investigated by case studies. This paper seeks to provide empirical evidence at an aggregate level, considering a sample of OECD countries, in the period 1990-2010, and applying both parametric and non-parametric approaches. According to the results obtained, organic agriculture seems negatively associated to per capita emissions. However, it does not appear robustly associated with improvements in environmental efficiency in the agricultural sector. These findings, conditioned to some extent by the availability of unbalanced panel data, suggest the need for further research to assess the role that organic agriculture could play in mitigating climate change.
\end{abstract}

Keywords: greenhouse gas emissions, organic agriculture, OECD countries, EKC, panel data, DEA, environmental efficiency

\section{Introduction}

The global warming phenomenon is increasingly affecting the ecological balance of our planet. Human activities are thought to be mainly responsible for this phenomenon, as they have led to increasing concentrations of greenhouse gases (GHG) in the atmosphere. Since adoption of the Kyoto Protocol, in 1997, the United Nations Framework Convention on Climate Change (UNFCCC) has been working to limit greenhouse gas emissions globally, though it has failed to achieve meaningful progresses in terms of effective policies stabilizing greenhouse gas concentrations in the atmosphere. Hopefully, the historic climate change deal between USA and China reached in November 2014 will encourage all major economies to reduce their emissions over the next two decades.

A noteworthy contribution to this process could come from the agricultural sector and, in particular, from organic agriculture, a production system aimed at protecting human health and delivering environmental improvements to landscapes, habitats, biodiversity, air and water quality. Yet, the potential benefits of organic agriculture are controversial. On one hand, some studies suggest that certain "regenerative" agriculture practices - generally associated to organic production - represent a means of both abating and sequestering carbon dioxide (Rodale Institute, 2014). Besides, organic farming could reduce nitrous oxide emissions, as it bans mineral fertilizers and it could limit methane from enteric fermentation by integrating longer-living livestock into farming (Scialabba \& Lindenlauf, 2010). On the other hand, according to evidence concerning particular crops, organic agriculture may imply higher emissions, because of the incorporation of legumes into the soil (Scialabba \& Lindenlauf, 2010), and mechanical measures required to control weeds and spread manure (Wood et al., 2006).

This study seeks to contribute to this debate by analysing the influence of organic farming on per capita GHG emissions and environmental efficiency in the agricultural sector, the latter being defined as the ability to increase agricultural production, while reducing (or not varying) inputs and abating total GHG emissions simultaneously.

Unlike the other literature on the theme, which typically involves case studies employing measures at farm level (Lundström, 1997; Lampkin, 1997; Dalgaard et al., 2001; Flessa et al., 2002; Wood et al., 2006), the present paper is the first analysis conducted using macroeconomic data and aggregate environmental indicators for a panel of OECD countries, observed in the period 1990-2010.

From a methodological point of view, both parametric and non-parametric approaches are employed, as different indicators of ecological performance are considered. Indeed, the first part of the study focuses on per capita 
agricultural emissions, adopting various econometric approaches to estimate an environmental Kuznets equation, addressing issues of unobserved heterogeneity, endogeneity, and non-stationarity. The second part considers non-parametric measures of environmental efficiency based on distance functions, which consider GHG emissions from the agricultural sector as outcomes of a production process, converting inputs into desirable and undesirable outputs.

The main findings show that organic agriculture tends to be negatively associated to per capita greenhouse gas emissions. However, the evidence of a positive contribution of organic farming to the environmental efficiency of the agricultural sector is somewhat weak.

The paper is organized as follows: next section describes the principles of organic agriculture, providing figures on its evolution in OECD countries over the past two decades. Further, it briefly reviews the expected impact of organic farming on GHG emissions, focusing on the carbon dioxide (CO2), nitrous oxide (N2O) and methane (CH4). Section 3 summarizes the data employed in the empirical analysis; section 4 analyses the relationship between organic farming and GHG emissions, while section 5 focuses on the relationship between organic farming and non-parametric measures of environmental efficiency. Section 6 concludes.

\section{Organic Agriculture}

\subsection{Definition and Evolution in OECD Countries}

Modern agricultural practices, characterizing the vast majority of farms in developed countries, pursue higher productivity by heavily employing chemical inputs, maximising soil fertility by monoculture, and intensive irrigation. Organic agriculture tends to reject these conventional practices, proposing a "holistic production management system" (FAO/WHO Codex Alimentarius Commission, 1999), which intends to preserve the health of present and future human generations and the environment. Indeed, according to the IFOAM's (International Federation of Organic Agriculture Movements) principle of health, organic agriculture aims at providing high quality and healthy food that contributes to well-being. To this end, the use of most synthetic inputs - such as fertilizers, pesticides and veterinary drugs - is banned. Furthermore, in light of the IFOAM's ecology principle, organic production has to be in harmony with the ecology, culture and scale of the local environment. To maintain and improve the common environment, organic producers are expected to recycle and manage resources and energy efficiently, acting in a cautious and responsible manner. Hence, organic farming might be regarded as the prototype of a more sustainable agriculture. In developed nations, compliance with organic standards is inspected and certified (generally by state and/or private agencies), and organic labelling may be used only by certified producers.

In OECD countries, consumers are aware of and concerned about health and environmental issues, and governments have adopted policies to foster the transition to organic production systems. Indeed, from their standpoint, organic agriculture represents not only a means to satisfy the growing demand for food quality and safety, but also "an economically, ecologically and socially sound option to reduce surpluses as well as an alternative to land set-aside" (Scialabba, 2000, p. 1). As a result, organic agriculture appears as a fast growing sector in the sample under study. Indeed, as Figure 1 shows, with the exception of Japan, the percentage of the agricultural area converted to organic production has tended to increase across all countries considered in the period from 1990 to 2010, Austria, Estonia and Switzerland reaching percentages of about 14\%, 10\% and 7\%, respectively, in the period 2004-2010. Moreover, when considering the extension of the area converted to organic production, except Denmark and Japan, all sample countries exhibit positive (average) growth rates of the converted area, Sweden, Chile and Greece being characterized by average percentage increases higher than $50 \%$. Finally, it has to be noted that the mentioned tendency to growth is still associated to low absolute levels, Australia, United States and Italy displaying the largest extensions in 2010, of beyond one million hectares. 


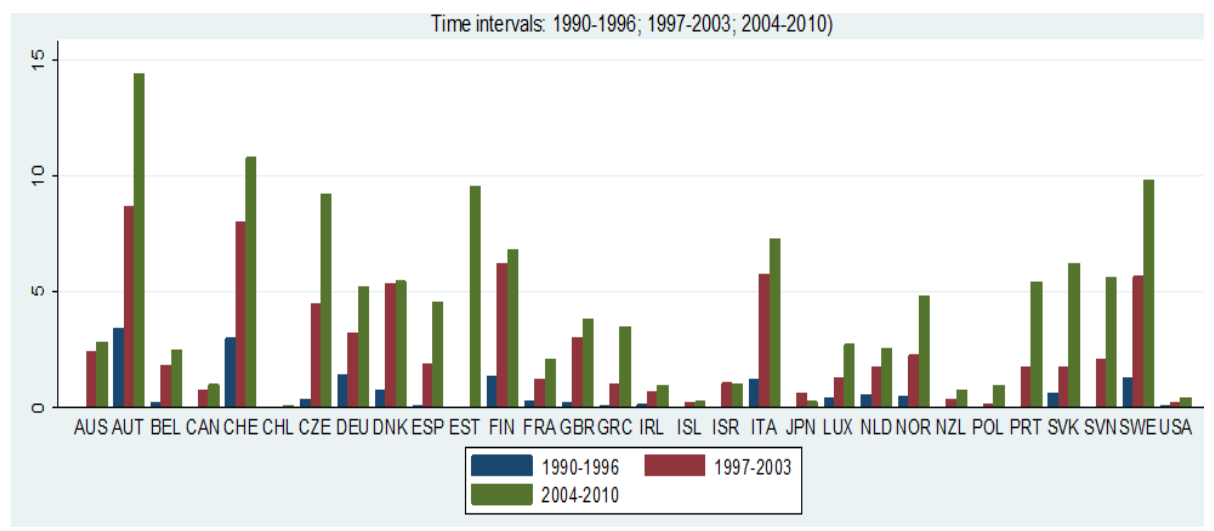

Figure 1. Average shares of total agriculture area converted to organic farming

\subsection{Organic Agriculture and GHG Emissions}

In the sample of OECD countries considered here greenhouse gas emissions from agriculture represent, on average, $14 \%$ of total GHG emissions. When considering the three main gases separately, nitrous oxide emissions from the agricultural sector account for approximately $71 \%$ of total $\mathrm{N} 2 \mathrm{O}$ emissions, while methane and carbon dioxide emissions from agriculture account for about $51 \%$ and $2 \%$ of total emissions, respectively.

The largest source of GHG emissions in agriculture is represented by livestock, which produce methane as part of their digestion (enteric fermentation). Further, nitrous oxide is released from the soil depending on the application of synthetic fertilizers and on certain methods of irrigation and tillage. Management of manure from livestock and burning crop residues also add to $\mathrm{CH} 4$ and $\mathrm{N} 2 \mathrm{O}$ emissions. Finally, $\mathrm{CO}_{2}$ emissions originate from the use of electricity and fossil fuels powering tractors and other agricultural machinery.

Since the organic agriculture movement advocates the protection and enhancement of the overall ecosystem, organic farmers are expected to implement practices intended to minimize air, water and soil pollution. However, according to the literature the impact of organic agriculture on direct greenhouse gas emissions is difficult to predict. The following review, which is not meant to be comprehensive, provides mixed evidence from empirical studies based on farm level data. Using a sample of organic and conventional Australian farms, Wood et al. (2006) find that the on-site (direct) energy use, and GHG are higher for organic farms. The authors ascribe such findings to a lower employment intensity and a possible higher use of fuels due to mechanical weed extirpation and manure distribution. On the other hand, Dalgaard et al. (2001), investigating energy use in Danish agriculture, find higher energy efficiency - computed as the ratio between yield and energy use - in organic systems. Furthermore, according to Flessa et al. (2002), organic farming is associated with lower emissions per hectare, even though there is no reduction in yield-related emissions. Moreover, higher quality soils- generally linked to organic production should require a reduced amount of fossil energy input per unit of food produced than the soils exploited by conventional systems (Refsgaard et al., 1998). Besides, as mentioned above, organic producers are expected to manage resources and energy more efficiently, being more sensitive to environmental problems, especially those caused by agricultural pollution.

As concerns the nitrous oxide emissions, soils used in conventional production are bound to emit higher amounts of $\mathrm{N} 2 \mathrm{O}$, due to the employment of mineral fertilizers and herbicides, which release $\mathrm{N} 2 \mathrm{O}$ in the atmosphere (Unwin et al., 1995; Stolze et al. 2000). What is more, conventional agriculture can be linked to higher emissions due to practices entailing lower soil aeration. On the other hand, higher $\mathrm{N} 2 \mathrm{O}$ emissions may be a consequence of higher tillage intensity, and the incorporation of manure and plant residues - typical practices of organic farming. However, the influence of soil conditions in this case is not yet clear (Reganold et al., 1993; Rochette et al., 2008; Scialabba \& Lindenlauf, 2010). Finally, concerning methane, organic farming livestock is predominantly ruminant and fed by roughage, entailing higher $\mathrm{CH} 4$ emissions. Further, since roughage is a low energy feedstuff, the growth rate of livestock is also slower, resulting in higher consumption per unit (Stolze et al., 2000). That said, the low density and longevity of livestock characterizing organic management are desirable features that may help address the problems connected with ruminant livestock that are not allowed to graze in modern farming, and abate $\mathrm{CH} 4$ emissions (Lampkin, 1997; Scialabba \& Lindenlauf, 2010).

\section{Data}

Data are drawn from the World Development Indicators (WDI 2014) and the OECD Agri-Environmental Indicators 
(2013). Table 1 describes the variables employed in the econometric and the data envelopment analysis and presents their summary statistics.

Table 1. Variables description and summary statistics

\begin{tabular}{|c|c|c|c|c|c|c|}
\hline Variable & Description & Mean & St. Dev. & Min & Max & Obs \\
\hline \multicolumn{7}{|c|}{ EKC equation } \\
\hline $\mathrm{CO} 2^{\text {(a) }}$ & Per capita $\mathrm{CO} 2$ emissions from agriculture & 0.1759 & 0.1098 & 0.0004 & 0.5454 & 620 \\
\hline $\mathrm{CH} 4^{\text {(b) }}$ & Per capita $\mathrm{CH} 4$ emissions from agriculture & 0.8658 & 1.2552 & 0.1129 & 6.8828 & 615 \\
\hline $\mathrm{N} 2 \mathrm{O}^{(\mathrm{b})}$ & Per capita $\mathrm{N} 2 \mathrm{O}$ emissions from agriculture & 0.7465 & 0.4905 & 0.0859 & 2.5655 & 615 \\
\hline org & $\begin{array}{l}\text { Share of agricultural land area under certified organic farm } \\
\text { management, \% total agricultural area }\end{array}$ & 3.1794 & 3.3161 & 0.0041 & 16.3718 & 404 \\
\hline gdp & Gdp per capita $(2010 \$)$ & 31948.96 & 15960.45 & 3931.487 & 86000.56 & 684 \\
\hline open & Imports + Exports of goods and services (\% GDP) & 79.5271 & 51.7745 & 15.6316 & 363.3172 & 679 \\
\hline \multicolumn{7}{|c|}{$x^{2}$} \\
\hline \multicolumn{7}{|l|}{ Inputs } \\
\hline i_land & Agricultural land area, Hectares & 1 & 2.7532 & 0.0031 & 11.7184 & 584 \\
\hline i_k & Tractors & 1 & 1.5955 & 0.0104 & 7.4460 & 404 \\
\hline i_l & Employment in agriculture & 1 & 1.4225 & 0.0037 & 7.2127 & 633 \\
\hline i_pest & Pesticide sales in agriculture, tonnes of active ingredients & 1 & 2.0989 & 0.0001 & 12.5887 & 530 \\
\hline \multicolumn{7}{|c|}{ Desirable output } \\
\hline o_agri_gdp & Agriculture GDP & 1 & 1.6466 & 0.0068 & 10.8963 & 572 \\
\hline \multicolumn{7}{|c|}{ GHG emissions: either inputs or undesirable outputs } \\
\hline $\mathrm{CO} 2$ & Total $\mathrm{CO} 2$ emissions from agriculture & 1 & 1.8853 & 0.0042 & 12.5061 & 620 \\
\hline $\mathrm{CH} 4$ & Total CH4 emissions from agriculture & 1 & 1.9760 & 0.0133 & 11.2821 & 615 \\
\hline $\mathrm{N} 2 \mathrm{O}$ & Total $\mathrm{N} 2 \mathrm{O}$ emissions from agriculture & 1 & 2.1108 & 0.0162 & 12.2376 & 615 \\
\hline \multicolumn{7}{|c|}{ 2-STAGE DEA } \\
\hline EE_i & Efficiency score obtained by treating GHG as inputs & 0.887 & 0.176 & 0.256 & 1 & 250 \\
\hline EE_o_1 & $\begin{array}{l}\text { Directional output Distance Function DDF (GHG as bad } \\
\text { outputs) }\end{array}$ & 0.052 & 0.128 & 0 & 0.700 & 250 \\
\hline EE_o_2 & DDF (GHG as bad outputs and all inputs fixed) & 0.032 & 0.086 & 0 & 0.595 & 250 \\
\hline EE_o_3 & DDF (GHG as bad outputs and all inputs fixed, except i_pest) & 0.036 & 0.088 & 0 & 0.597 & 250 \\
\hline edu & Labor force with secondary education (\% of total) & 50.791 & 17.054 & 10.8 & 80.2 & 212 \\
\hline ge (d) & Government effectiveness, from World Bank WGI database & 1.428 & 0.590 & 0.404 & 2.345 & 138 \\
\hline
\end{tabular}

Note. (a) tons per capita; (b) tons of $\mathrm{CO} 2$ equivalent per capita; (c) all variables entering the DEA are normalized with respect to their sample mean; (d)perceptions of the quality of public services, the quality of the civil service and the degree of its independence from political pressures, the quality of policy formulation and implementation, and the credibility of the government's commitment to such policies.

Comparing the three gases emissions ( $\mathrm{N} 2 \mathrm{O}$ and $\mathrm{CH} 4$ being expressed in $\mathrm{CO} 2$ equivalents), methane and nitrous oxide seem contributing much more to the agriculture emissions than does carbon dioxide. Besides, Figure A1, in the Appendix, shows the evolution of (the mean values of) per capita $\mathrm{CO} 2, \mathrm{~N} 2 \mathrm{O}$ and $\mathrm{CH} 4$ emissions in the sample over time. Consistently with the OECD (2013) report, the indication is that per capita GHG emissions, on the average, have been slightly declining in the countries considered.

Due to the lack of comparable aggregate data on net emissions from the agriculture sector, all emissions considered in this work are gross direct emissions from agriculture, within a national territory, excluding sinks and indirect effects. Hence, the present analysis does not account for the sequestration potential of organically managed soils, nor for other indirect beneficial influences, such as the exclusion of synthetic fertilizers and pesticides, precluding the emissions associated with the chemical synthesis and transportation of these inputs.

Finally, the presence of stochastic trends in the data is investigated by performing Fisher-type tests (ADF and Phillips-Perron tests) and the Im-Pesaran-Shin (2003) panel unit-root test on all variables entering the Environmental Kuznets Curve (EKC). All these tests are corrected to mitigate cross-sectional dependence (Levin et al., 2002), and computed both with and without a trend. Looking at the results - reported by Table A1 in the Appendix - the null hypothesis that all panels contain unit roots is always rejected only in the organic share (org) variable case. In the other instances, the results are mixed. In addition, none of the variables is integrated of order 2 , as a further test on the first-differenced variables always turned out to be insignificant. These findings will be taken 
into account in the following analysis (Note 1).

\section{Organic Agricultural and Per Capita GHG Emissions}

\subsection{The Econometric Model}

In this section, the Environmental Kuznets Curve framework is adopted to investigate the relationship between organic agriculture and per capita GHG emissions. In its simplest form, the EKC hypothesis suggests the existence of a bell-shaped relationship between emissions and per capita income: higher levels of wealth are expected to increase pollution at lower levels of income, whilst an increase of per capita income should determine a reduction in emissions beyond a certain threshold. In other words, deterioration of environmental quality is regarded as a temporary phenomenon associated with the early stages of economic development, bound to decline in subsequent phases. According to Panayotou (1993), the driving forces of this inversion are structural changes towards less polluting industries, technological progress limiting energy use and waste, and higher environmental awareness, that leads policy makers to adopt stricter environmental regulations (Note 2). Whilst pioneering works pay particular attention to the estimated turning point beyond which emissions should decrease (Panayotou, 1993, Grossman \& Krueger, 1995; Galeotti et al., 2006), a large number of recent studies adopts the EKC to assess the impact of specific potential determinants of pollution, such as the nuclear energy production as well as cultural, institutional and political economy factors (Torras \& Boyce, 1998; Barrett \& Graddy, 2000; Welsch, 2004; Mazzanti et al., 2008; Leitão, 2010; Iwata et al., 2010; 2011).

In the light of the literature so far depicted, the empirical equation adopted in this study - representing a long-term relationship - is the following:

$$
e_{i t}=\alpha+\alpha_{1} \operatorname{org}_{i t}+\alpha_{2} g d p_{i t}+\alpha_{3} g d p_{i t}^{2}+\alpha_{4} \text { open }_{i t}+v_{i t}
$$

where the dependent variable is per capita emissions (alternatively $\mathrm{CO} 2, \mathrm{~N} 2 \mathrm{O}$ or $\mathrm{CH} 4$ ). On the right hand side, org is the share of agricultural land area under certified organic farm management, whilst $g d p$ is per capita income, and open is a measure of trade openness. The inclusion of the latter regressor is meant to account for the widely shared notion that trade is an important explanatory factor of pollution (Suri \& Chapman, 1998; Dinda, 2004) (Note 3). All variables are in logarithmic form. Finally, $v_{i t}$ is a white noise error term. In the next section, as a robustness check, the benchmark equation (1) will be extended with other potential determinants of pollution, which have been suggested by the literature (e.g. Torras \& Boyce, 1998; Iwata et al., 2010): a measure of education, energy consumption, and urbanization (Note 4).

\subsection{Methodology}

The estimation of equation (1) may be plagued by several econometric problems, which have been addressed by the most recent EKC literature. First, concerns of endogeneity may arise if environmental quality can influence income levels, especially in developing countries where land degradation may impact on agricultural production (Holtz-Eakin \& Selden, 1995; Cole et al., 1997; Cole, 2003). Further, when the estimation samples is composed by different countries, the issue of heteroscedasticity has to be addressed (Stern et al., 1996). Besides, in the context of panel data, it is necessary to control for unobserved country characteristics (such as climatic and geographical factors), that may affect the environmental quality in each country. To this aim, static panel data estimators have been widely employed (e.g. Grossman \& Krueger, 1995, Orubu \& Omotor, 2011). Moreover, dynamics adjustment has been accounted for either by allowing for correlation in the regression residuals or by adopting dynamic panel estimators (Kearsley \& Riddel, 2010; Lee et al., 2010; Leitão \& Shahbaz, 2013). Last not least, when considering time-series or panel data with a long time dimension, GDP as well as other variables included in the regression model, may exhibit stochastic trends. If such non-stationary variables do not cointegrate in the long run, then the estimated relationships are spurious (Perman \& Stern, 2003; Stern, 2004; Wagner, 2014).

Evidently, the econometric issues above depicted are dependent on the type of data at hand. In the present work, an unbalanced macroeconomic panel is considered, made of 30 OECD countries (listed in Figure 1) observed for 21 years (1990-2010), at most. Since the diagnostic statistics for integration (presented in the Data section) do not provide definite evidence on the non-stationarity of the variables employed, my empirical strategy is adopting the bulk of methods suggested by the EKC literature, providing results that are not conditional on a specific methodological choice. Thus, besides OLS and static panel estimations (either FE or RE, according to a Hausman test), to gauge dynamics effects, I adopt the Prais-Winsten method (obtaining panel-corrected standard errors accounting both for heteroskedasticity and correlation across and within panels) and the Blundell and Bond (1998) model, known as GMM-SYS estimator. The latter one not only allows to control for specific individual effects (as the FE and RE estimators do), but also to account for dynamic adjustment - including a lagged dependent variable in the regressors set - and to relax the strict exogeneity assumption, which ensures the consistency of both RE and 
FE models. The GMM-SYS estimator consists of two steps: the data are first differenced in order to eliminate the unobserved fixed effects, and then valid instrumental variables are employed in order to cope with the endogeneity problem posed by the dynamic adjustment term and (possibly) by some regressors. Blundell and Bond (1998) GMM procedure exploits both the entire set of internal instruments (lagged values of the regressors) for the model in first differences, under the assumption of white noise errors, and extra orthogonality conditions, using the lagged differences of the regressors as instruments for the equation in levels. In the present study the number of time periods is comparable to that of countries, thus the GMM estimator may suffer from a problems of instrument proliferation. To improve the small samples properties of the GMM estimator, I follow two main strategies, limiting the instruments to the minimum fixed number (1) or collapsing the instrument matrix (Breitung, 2015) (Note 5).

Finally, to tackle issues of non-stationarity, and to relax the homogeneity assumption on the slope coefficients, I adopt the Pooled Mean Group (PMG) estimator for dynamic heterogeneous panels (Pesaran et al., 1999; Martínez-Zarzoso \& Bengochea-Morancho, 2004; Iwata et al., 2011). The PMG estimator allows short-run coefficients (and speed of adjustment) to differ across countries, imposing homogeneity only on long-run coefficients. What is more, it represents a means for determining the long term relationship among variables with different order of integration, $\mathrm{I}(0)$ or I(1), which seems the case of the present work, as the panel unit root tests results indicate (Note 6). To illustrate the PMG model, taking the maximum lag equal to one (Note 7) and assuming that the long run EKC relationship is represented by equation (1) it is possible to specify the following ARDL $(1,1$, $1,1,1)$ model:

$$
\begin{gathered}
e_{i t}=\beta_{10 i} \text { org }_{i t}+\beta_{11 i} \text { org }_{i t-1}+\beta_{20 i} g d p_{i t}+\beta_{21 i} g d p_{i t-1}+\beta_{30 i} g d p_{i t}^{2}+\beta_{31 i} g d p_{i t-1}^{2}+\beta_{40 i} \text { open }_{i t}+ \\
\beta_{41 i} \text { open }_{i t-1}+\lambda_{i} e_{i t-1}+\mu_{i}+\varepsilon_{i t}
\end{gathered}
$$

Following Pesaran et al. (1999), a re-parameterisation of this model yields the error correction representation:

$$
\begin{gathered}
\Delta e_{i t}=\phi_{i}\left(e_{i t-1}-\alpha_{0 i}-\alpha_{1 i} \operatorname{org}_{i t}-\alpha_{2 i} g d p_{i t}+\alpha_{3 i} g d p_{i t}^{2}+\alpha_{4 i} \text { open }_{i t}\right)-\beta_{11 i} \Delta \operatorname{org}_{i t} \\
-\beta_{21 i} \Delta g d p_{i t}-\beta_{31 i} \Delta g d p_{i t}^{2}-\beta_{41 i} \text { open }_{i t}+\varepsilon_{i t}
\end{gathered}
$$

where $\alpha_{0 i}=\frac{\mu_{i}}{1-\lambda_{i}} ; \alpha_{s i}=\frac{\beta_{s 0 i}+\beta_{s 1 i}}{1-\lambda_{i}}$ for $s=1 \ldots 4$; and $\phi_{i}=-\left(1-\lambda_{i}\right)$.

Model (3) may be estimated adopting three main panel approaches, which allow for different degrees of parameter heterogeneity. Whilst (static or dynamic) fixed-effects estimators restrict all slope parameters to be identical across countries, allowing for country specific intercepts, the Mean Group estimator (Pesaran \& Smith, 1995) imposes no cross-country coefficients constraints and is estimated on a country-by-country basis, the final parameters being simple averages of the individual country coefficients. Finally, the PMG estimator is an intermediate approach which allows short-term parameters and the adjustment speed to vary across countries, and impose cross-country homogeneity only on the long-run coefficients. Since the present study is focused on OECD countries, characterized by similar economic and institutional structures, and accessing similar technologies, it seems appropriate assuming common long-run coefficients, while allowing the speed of adjustment (to the steady state) to vary across countries. Further, on a statistical ground, a Hausman test tends to confirm the long-run homogeneity restriction underlying the PMG estimator (see Table 3).

\subsection{Results}

Table 2 reports the output obtained adopting OLS, Prais-Winsten, static panel methods, and the GMM-SYS estimator, while Table 3 displays the PMG results. Incidentally, all regressions include a trend and the relative standard errors (omitted) are always robust for any pattern of heteroskedasticity. 
Table 2. EKC estimation results

\begin{tabular}{|c|c|c|c|c|c|c|c|c|c|c|c|c|}
\hline & \multicolumn{3}{|c|}{ OLS } & \multicolumn{3}{|c|}{ PRAIS-WINSTEN } & \multicolumn{3}{|c|}{ FE/RE } & \multicolumn{3}{|c|}{ GMM-SYS } \\
\hline & $\mathrm{CO2}$ & CH4 & $\mathrm{N2O}$ & $\mathrm{CO} 2$ & $\mathrm{CH} 4$ & N2O & $\mathrm{CO} 2$ & $\mathrm{CH} 4$ & $\mathrm{N2O}$ & $\mathrm{CO2}$ & $\mathrm{CH} 4$ & $\mathrm{~N} 2 \mathrm{O}$ \\
\hline & (1) & (2) & (3) & (4) & (5) & (6) & (7) & (8) & (9) & (10) & (11) & (12) \\
\hline \multirow[t]{2}{*}{ org } & $-0.13 * * *$ & $-0.21 * * *$ & $-0.13 * * *$ & -0.038 & $-0.028 * *$ & $-0.020 * * *$ & 0.021 & 0.003 & 0.000 & $-0.035 * *$ & $-0.004 * *$ & -0.006 \\
\hline & 0.000 & 0.000 & 0.000 & 0.113 & 0.016 & 0.003 & 0.719 & 0.741 & 0.977 & 0.013 & 0.05 & 0.14 \\
\hline \multirow[t]{2}{*}{ gdp } & $5.463 * * *$ & $7.574 * * *$ & $4.019 * * *$ & 3.03 & $-3.069 * * *$ & 0.256 & -4.916 & -0.901 & $1.515^{*}$ & $2.085 * * *$ & $0.469 * *$ & $0.481 *$ \\
\hline & 0.008 & 0.000 & 0.005 & 0.329 & 0.001 & 0.767 & 0.516 & 0.267 & 0.073 & 0.006 & 0.022 & 0.064 \\
\hline \multirow[t]{2}{*}{$\operatorname{gdp}^{2}$} & $-0.28 * * *$ & $-0.36^{* * *}$ & $-0.19 * * *$ & -0.166 & $0.171^{* * *}$ & -0.009 & 0.316 & 0.044 & $-0.068 *$ & $-0.103 * * *$ & $-0.023 * *$ & $-0.024 *$ \\
\hline & 0.006 & 0.000 & 0.007 & 0.289 & 0.000 & 0.829 & 0.371 & 0.262 & 0.098 & 0.007 & 0.022 & 0.062 \\
\hline \multirow[t]{2}{*}{ open } & $0.228 * * *$ & $0.355^{* * *}$ & $0.265 * * *$ & -0.106 & $-0.066^{*}$ & $0.104^{* * *}$ & -0.687 & -0.189 & -0.096 & $0.123^{* * *}$ & $0.010^{*}$ & $0.020 *$ \\
\hline & 0.006 & 0.000 & 0.000 & 0.397 & 0.076 & 0.003 & 0.578 & 0.223 & 0.467 & 0.003 & 0.097 & 0.075 \\
\hline \multirow[t]{2}{*}{ trend } & -0.004 & 0.014 & -0.006 & -0.006 & -0.003 & $-0.015 * * *$ & $-0.051 * * *$ & $-0.008 * * *$ & $-0.015 * * *$ & 0.003 & 0.001 & 0.001 \\
\hline & 0.638 & 0.11 & 0.397 & 0.506 & 0.357 & 0.000 & 0.006 & 0.005 & 0.000 & 0.261 & 0.199 & 0.317 \\
\hline \multirow[t]{2}{*}{ L.Dep. Var. } & & & & & & & & & & $1.040^{* * *}$ & $0.992 * * *$ & $0.987 * * *$ \\
\hline & & & & & & & & & & 0.000 & 0.000 & 0.000 \\
\hline Obs & 387 & 404 & 404 & 387 & 404 & 404 & 387 & 404 & 404 & 374 & 390 & 390 \\
\hline Countries & 28 & 30 & 30 & 28 & 30 & 30 & 28 & 30 & 30 & 28 & 30 & 30 \\
\hline \multicolumn{13}{|l|}{$\mathrm{F}$ (or } \\
\hline Wald) test & 9.33 & 47.27 & 24.58 & 30.27 & 154.64 & 225.39 & 12.37 & 138.47 & 133.35 & 324.15 & 53554.58 & 6634.48 \\
\hline$p$-value & 0.000 & 0.000 & 0.000 & 0.000 & 0.000 & 0.000 & 0.000 & 0.000 & 0.000 & 0.000 & 0.000 & 0.000 \\
\hline AR1 & & & & & & & & & & -1.64 & -2.83 & -3.15 \\
\hline p-value & & & & & & & & & & 0.102 & 0.005 & 0.002 \\
\hline AR2 & & & & & & & & & & 1.65 & 0.79 & 0.48 \\
\hline$p$-value & & & & & & & & & & 0.100 & 0.429 & 0.633 \\
\hline Hansen test & & & & & & & & & & 25.23 & 23.12 & 22.35 \\
\hline$p$-value & & & & & & & & & & 1 & 1 & 1 \\
\hline
\end{tabular}

Note. For the description of the variables see Table 1. All variables are in logarithmic form. In Italics are reported the p-values of the tests. Superscripts $* * * * *$ and $*$ denote statistical significance at the 1, 5 and 10 percent level, respectively. Constant always included but not reported. AR1 and AR2 stand for Arellano-Bond test for AR(1) in first differences and Arellano-Bond test for AR(2) in first differences, respectively. For the Hansen test, the null hypothesis is the validity of the over-identifying restrictions.

Looking first at Table 2, the EKC bell-shaped relationship between per capita income and GHG tends to be confirmed across most of the estimations performed. Indeed, except the $\mathrm{CH} 4$ case in the Prais-Winston regression, the GDP and its squared term parameters tend to be positive and negative, respectively, being mostly statistically significant. Furthermore, the openness measure coefficient tends to be positive when significant. Focusing on the variable of interest, the share of land converted to organic agriculture seems exerting a negative impact on per capita emissions. Indeed, except for the FE/RE case, its estimated coefficient tends to be negative and statistically significant. Besides, it is worth noting that its magnitude seems decreasing when passing from the OLS to the GMM estimates, thus the impact of organic farming is downsized when accounting for country specific effects, dynamic adjustment and endogeneity (Note 8 ).

Considering Table 3, the negative sign of the key variable is confirmed in the long-run relationship, across all greenhouse gases considered (Note 9). Moreover, the estimated impact based on the PMG model is higher than in the GMM instances. In other words, the long-run influence of organic agriculture on GHG emissions seem greater. Yet, the Hausman test (reported in the last row of Table 3) is significant in the methane case, hence I don't emphasize the relative results, as the homogeneity assumption is rejected. 
Table 3. EKC estimation results

\begin{tabular}{|c|c|c|c|c|c|c|}
\hline & \multicolumn{3}{|l|}{ PMG } & \multicolumn{3}{|c|}{ PMG - AGRI GDP } \\
\hline & $\mathrm{CO} 2$ & CH4 & $\mathbf{N 2 O}$ & $\mathrm{CO} 2$ & CH4 & $\mathbf{N 2 O}$ \\
\hline & (1) & (2) & (3) & (4) & (5) & (6) \\
\hline \multicolumn{7}{|l|}{ Long-run } \\
\hline \multirow[t]{2}{*}{ org } & $-0.234 * * *$ & $-0.091 * * *$ & $-0.032 * * *$ & $-0.308 * * *$ & $-0.304 * *$ & $-0.034 * * *$ \\
\hline & 0.000 & 0.000 & 0.000 & 0.000 & 0.043 & 0.002 \\
\hline \multirow[t]{2}{*}{ gdp } & $13.609 * * *$ & $5.510 * * *$ & 1.657 & $6.471 * * *$ & 3.356 & -0.762 \\
\hline & 0.001 & 0.001 & 0.375 & 0.000 & 0.356 & 0.155 \\
\hline \multirow[t]{2}{*}{$\operatorname{gdp}^{2}$} & $-0.667 * * *$ & $-0.260 * * *$ & -0.068 & $-0.359 * * *$ & -0.161 & 0.043 \\
\hline & 0.001 & 0.000 & 0.424 & 0.000 & 0.394 & 0.106 \\
\hline \multirow[t]{2}{*}{ open } & $-0.850 * * *$ & $0.407 * * *$ & $0.209 * * *$ & $0.816^{* * *}$ & $-1.496^{*}$ & $0.386 * * *$ \\
\hline & 0.000 & 0.000 & 0.001 & 0.000 & 0.061 & 0.000 \\
\hline \multirow[t]{2}{*}{ trend } & 0.017 & $-0.007 * * *$ & $-0.010 * * *$ & $0.032 * * *$ & $-0.047 * *$ & $0.009 * *$ \\
\hline & 0.106 & 0.004 & 0.000 & 0.000 & 0.014 & 0.017 \\
\hline \multicolumn{7}{|l|}{ Short-run } \\
\hline \multirow[t]{2}{*}{$\mathrm{ec}$} & $-0.471 * * *$ & $-0.161 * * *$ & $-0.307 * * *$ & $-0.403 * *$ & 0.017 & $-0.256^{* *}$ \\
\hline & 0.005 & 0.006 & 0.001 & 0.012 & 0.253 & 0.031 \\
\hline \multirow[t]{2}{*}{$\Delta$ org } & 0.474 & 0.003 & 0.04 & 0.563 & 0.004 & $0.039 * * *$ \\
\hline & 0.178 & 0.732 & 0.103 & 0.169 & 0.584 & 0.006 \\
\hline \multirow[t]{2}{*}{$\Delta \mathrm{gdp}$} & 413.852 & $35.260 * * *$ & 25.956 & -18.013 & $4.838^{* *}$ & $10.872 * * *$ \\
\hline & 0.277 & 0.008 & 0.233 & 0.556 & 0.023 & 0.003 \\
\hline \multirow[t]{2}{*}{$\Delta \mathrm{gdp}^{2}$} & -19.876 & $-1.735^{* * *}$ & -1.206 & 0.835 & $-0.232 * *$ & $-0.551 * * *$ \\
\hline & 0.275 & 0.008 & 0.244 & 0.594 & 0.028 & 0.005 \\
\hline \multirow[t]{2}{*}{$\Delta$ open } & 0.485 & -0.031 & -0.081 & -0.013 & -0.019 & -0.017 \\
\hline & 0.238 & 0.501 & 0.515 & 0.948 & 0.559 & 0.604 \\
\hline Obs & 258 & 258 & 238 & 197 & 197 & 197 \\
\hline Countries & 17 & 17 & 15 & 13 & 13 & 13 \\
\hline Hausman test & 4.11 & 48.66 & 1.43 & 3.51 & 16.84 & 7.06 \\
\hline p-value & 0.534 & 0.000 & 0.921 & 0.477 & 0.021 & 0.133 \\
\hline
\end{tabular}

Note. For the description of the variables see Table 1. All variables are in logarithmic form. In Italics are reported the p-values of the tests. Superscripts $* * *, * *$ and $*$ denote statistical significance at the 1,5 and 10 percent level, respectively. Constant always included but not reported. In columns 4-6, GDP is per capita GDP from the agricultural sector, and open is the sum of exports and imports of agricultural raw materials (as a share of GDP).

To verify the robustness of the findings so far described, I run a battery of regressions, modifying the baseline specification. First, I add to the model a control for the financial crisis (i.e. a dummy variable coded one for the years post 2007, and zero otherwise). As it never turns out to be significant, while the main result remains substantially confirmed, these estimates are omitted and available on request. Besides, since the GHG emissions here considered derives from the agricultural sector, I replace per capita GDP with per capita GDP from the agricultural sector, and the openness indicator with the sum of exports and imports of agricultural raw materials (as a share of GDP). Since findings tend to be unaltered, for the sake of conciseness, Table 3 (columns 4-6) reports only the estimations obtained employing the PMG estimator, which are consistent with those so far presented, the only noticeable difference being a positive short-run coefficient of org in the $\mathrm{N} 2 \mathrm{O}$ case.

Finally, I add to the baseline model, three extra explanatory variables: national energy consumption, urban population and measure of secondary education (all of them scaled by population and considered in logarithm form). As Table A2 (in the Appendix) shows, results concerning the key variable are confirmed. However, adding the above mentioned regressors yield severe convergence problems for the PMG estimator, which could not be avoided even changing the optimization technique. From this point of view, the analysis would have certainly benefited from the availability of longer time spans. Therefore, further analysis is needed to confirm the existence of a causal relationship.

\section{Organic Farming and Environmental Efficiency}

As aforementioned, when estimating an EKC one disregards the fact that agricultural emissions are outcomes of a production process. From this standpoint, the key question is whether modification of the production process from conventional to organic farming may lead to improvements in environmental efficiency. To this end, I shall first measure the environmental efficiency of agricultural production at country level with Data Envelopment Analysis 
(DEA) and then examine whether it is influenced by organic farming (Note 10).

\subsection{Computing Environmental Efficiency}

The DEA methodology - introduced by Charnes et al. (1978) and extensively employed to obtain non-parametric measures of firms, sectors or countries efficiency - is here adopted to retrieve alternative measures of agricultural production efficiency, which are based on distance functions from a benchmark production frontier (Note 11).

The basic idea underlying such distances is that, at any point in time, we can draw a piece-wise production frontier, locus of technically efficient input-output combinations, given the existing technology. Hence, the distance between this frontier and a certain combination not belonging to the frontier can be regarded as a measure of technical inefficiency. More formally, an intput distance function gauges the largest proportional contraction of the inputs, given an output vector, and may be defined as follows:

$$
D(x, q)=\max \{\delta:(x / \delta) \in L(q)\}
$$

where $L(q)$ is the set of all inputs, $x$, which can produce the output vector, $q$. A simple approach to take into account pollution in this framework is to include polluting emissions in $x$, as additional inputs of the production process (Riccardi et al., 2012). The Farrell (1957) input oriented measure of technical efficiency is reciprocal to the aforementioned input distance function, and can be retrieved solving the following linear program:

$$
\begin{gathered}
\min _{\lambda, \phi} \phi \\
\text { s. } t .: \sum_{j=1}^{n} \lambda_{j} q_{r j}^{g} \geq q_{r j}^{g} \quad r=1, \ldots, p \\
\sum_{j=1}^{n} \lambda_{j} x_{i j} \leq \phi x_{i j} \quad i=1, \ldots, m \\
\sum_{j=1}^{n} \lambda_{j}=1 \quad j=1, \ldots, n \\
\lambda_{j} \geq 0
\end{gathered}
$$

Where $q_{r j}^{g}$ is the $r t h$ good output produced by the $j t h$ country; $x_{i j}$ is the ith input used by the $j t h$ country, and $\lambda_{j}$ is an intensity factor associated to each country. When considering emissions as inputs, the optimal value $\phi^{*}$ may be regarded as an environmental efficiency score for the ith country, ranging between 0 and 1 , with a value of 1 corresponding to a point on the frontier. In this framework, outputs are assumed as strongly disposable: the disposal of any output does not imply any cost in terms of other outputs reduction.

Alternative measures of environmental efficiency may be based on the directional output distance function, which is a generalization of the radial distance function above described, since efficiency may be measured in any direction from a given point of the production possibility set, allowing both inputs and outputs to simultaneously change (Chung et al., 1997; Färe et al., 2003; Riccardi et al., 2012) (Note 12).

Thanks to this flexibility, the directional output distance function may account for both desirable and undesirable outputs, generated by a production process. In this case, the output set is modified to ensure the following properties: (i) null-jointness, meaning that the only way to produce zero bad output is to produce zero good output; (ii) weak disposability of undesirable output, imposing that a reduction in bad output must imply a proportional contraction in good output; (iii) strong disposability of desirable output.

Different specifications of the direction vector allow to obtain different measures of efficiency. In this work, when treating GHG emissions as bad outputs, efficiency is initially defined as the ability to increase desirable outputs $\left(q^{g}\right)$ while reducing inputs $(x)$ and undesirable outputs $\left(q^{b}\right)$ simultaneously. Hence, the directional output distance function is:

$$
\vec{D}\left(x, q^{g}, q^{b} ; d\right)=\max \left\{\theta:\left(q^{g}+\theta d^{g}, q^{b}-\theta d^{b}\right) \in P\left(x-\theta d^{x}\right)\right\}
$$

Where $d=\left(d^{g},-d^{b},-d^{x}\right)$ is the direction vector, indicating expansion of the good output in the $d^{g}$ direction and contraction of polluting emissions and inputs in $d^{b}$ and $d^{x}$ directions, respectively. Alternatively, efficiency is regarded as the ability to increase good outputs, while reducing bad outputs without varying inputs, i.e. the direction vector is defined as $d=\left(d^{g},-d^{b}, 0\right)$. Finally, to account for the fact that organic farming should be associated to a lower employ of pesticides, efficiency is also defined as the ability to increase good outputs while reducing both bad outputs and the pesticides input, without varying the other inputs.

To give a simple illustration, one can consider the case of a single desirable output and a single undesirable output, drawing an output set $\mathrm{P}(x)$ as in Figure 1. The value of $\theta$ measures the distance between the combination $\left(q^{g}, q^{b}\right)$ and a point on the production frontier, $\left(q^{g}+\theta d^{g}, q^{b}-\theta d^{b}\right)$, namely the maximum feasible expansion of good output and reduction of bad output given the production technology $\mathrm{P}(x)$ and the direction vector $d$. Hence, when 
adopting a directional output distance function, efficiency is attained when $\theta=0$.

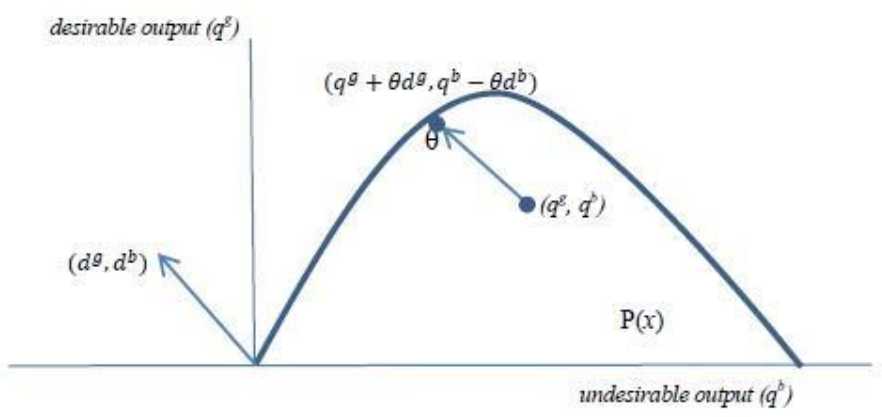

Figure 2. Directional distance function

To compute the aforementioned measures of environmental efficiency for the agricultural sector of each sample country, I consider agricultural GDP as the desirable output; CO2, N2O and CH4 emissions as undesirable outputs; land, labor, capital and pesticides employed by the agricultural sector as inputs (see Table 2 for a more detailed description). To avoid the influence of different measurement units, all these variables have been normalized with respect to their means. Finally, all measures have been computed under the variable returns to scale hypothesis.

Table 4 reports the average efficiency measures for each country over the sample years, EE_i being the measure of efficiency obtained by treating GHG as inputs, while EE_o_1, EE_o_2 and EE_o_3 denoting the measures obtained considering emissions as undesirable outputs. In column 1 efficiency is attained when EE_i is equal to one, while in the other columns when EE_o_1, EE_o_2 or EE_o_3 are zero. Hence, Germany, France and Slovenia are classified as fully efficient in view of the measures based on directional distance functions, while Estonia, Netherland and Norway appear as fully efficient across all the measures of environmental efficiency considered.

Table 4. Environmental efficiency measures (mean values)

\begin{tabular}{lllll}
\hline Country & EE_i & EE_o_1 & EE_o_2 & EE_o_3 \\
\hline & $(1)$ & $(2)$ & $(3)$ & $(4)$ \\
Austria & 0.6320 & 0.0617 & 0.0584 & 0.0593 \\
Belgium & 0.9407 & 0.0010 & 0.0009 & 0.0009 \\
Switzerland & 0.9820 & 0.0004 & 0.0003 & 0.0004 \\
Czech Republic & 0.7206 & 0.0650 & 0.0598 & 0.0632 \\
Germany & 0.8696 & 0 & 0 & 0 \\
Denmark & 0.9255 & 0.0039 & 0.0015 & 0.0039 \\
Spain & 0.9877 & 0.6023 & 0.3363 & 0.3332 \\
Estonia & 1 & 0 & 0 & 0 \\
Finland & 0.9967 & 0.0207 & 0.0114 & 0.0133 \\
France & 0.9805 & 0 & 0 & 0 \\
Greece & 0.9882 & 0.0586 & 0.0550 & 0.0563 \\
Ireland & 0.7620 & 0.0082 & 0.0065 & 0.0071 \\
Italy & 0.9955 & 0.0204 & 0.0097 & 0.0146 \\
Japan & 0.9945 & 0.0004 & 0.0003 & 0.0004 \\
Netherlands & 1 & 0 & 0 & 0 \\
Norway & 1 & 0 & 0 & 0 \\
Poland & 0.4063 & 0.1619 & 0.0745 & 0.1171 \\
Portugal & 0.7424 & 0.0738 & 0.0696 & 0.0701 \\
Slovak Republic & 1 & 0.0021 & 0 & 0 \\
Slovenia & 0.8075 & 0 & 0 & 0 \\
Sweden & 0.9419 & 0.0418 & 0.0179 & 0.0393 \\
\hline
\end{tabular}

Note. For the description of the variables see Table 1. In column 1 efficiency is attained when EE_i $=1$, in columns 2-4 when EE_o $=0$. 


\subsection{A Model of Environmental Efficiency Determinants}

The second step of the analysis aims at assessing the influence of organic farming on environmental efficiency, controlling for other factors that may determine the efficiency levels of the agricultural sector in each country. The literature investigating the determinants of environmental efficiency suggests the relevance of three main drivers, such as the enforcement of environmental regulations, environmental awareness, and economic development (Watanabe \& Tanaka, 2007; Wu, 2010). In my specification, these drivers are accounted for by a measure of government effectiveness, drawn from the World Bank WGI database, a measure of education and income per capita (see Table 2 for further details). Given the panel structure of the data, it is also possible to control for unobservable time-invariant factors, which are country specific and might condition the social and economic attitude towards environmental issues (for instance cultural, institutional or natural conditions). To this aim, fixed or random panel estimators are employed, on the base of Hausman tests results. Besides, to account for the censored nature of the efficiency measures a Tobit random effects model is adopted. Finally, to mitigate the potential endogeneity of the share of organic agriculture, the relative variable is lagged one year.

Columns 1 and 5 of Table 5 show the results obtained using as dependent variable EE_i (measure of efficiency obtained by treating GHG as inputs) while columns 2-4 and 6-8 those based on EE_o_1, EE_o_2 and EE_o_3 (obtained considering emissions as undesirable outputs).

Table 5. Second stage estimation results

\begin{tabular}{|c|c|c|c|c|c|c|c|c|}
\hline & \multicolumn{4}{|l|}{ FE/RE } & \multicolumn{4}{|c|}{ Random Effects Tobit } \\
\hline & EE_i & EE_o_1 & EE_o_2 & EE_o_3 & EE_i & EE_o_1 & EE_o_2 & EE_o_3 \\
\hline & (1) & (2) & (3) & (4) & $(5)$ & (6) & (7) & (8) \\
\hline \multirow[t]{2}{*}{ org } & $0.016^{* *}$ & -0.005 & -0.003 & -0.002 & 0.016 & $-0.011 * * *$ & -0.001 & -0.002 \\
\hline & 0.035 & 0.223 & 0.467 & 0.556 & 0.165 & 0.004 & 0.792 & 0.653 \\
\hline \multirow[t]{2}{*}{ gdp } & -0.024 & $-0.064 * *$ & 0.018 & 0.009 & -0.089 & $-0.071 *$ & $0.164 * * *$ & $0.163 * * *$ \\
\hline & 0.741 & 0.044 & 0.817 & 0.915 & 0.495 & 0.094 & 0.001 & 0.001 \\
\hline \multirow[t]{2}{*}{ edu } & $-0.003 *$ & $-0.003 * * *$ & -0.0001 & -0.001 & -0.003 & $-0.003 *$ & -0.003 & -0.002 \\
\hline & 0.096 & 0.001 & 0.948 & 0.718 & 0.497 & 0.092 & 0.122 & 0.24 \\
\hline \multirow[t]{2}{*}{ ge } & 0.034 & 0.003 & $-0.177 * * *$ & $-0.182 * * *$ & $0.126^{*}$ & -0.007 & $-0.260 * * *$ & $-0.246^{* * * *}$ \\
\hline & 0.544 & 0.913 & 0.000 & 0.000 & 0.082 & 0.765 & 0.000 & 0.000 \\
\hline Obs & 97 & 97 & 97 & 97 & 97 & 97 & 97 & 97 \\
\hline Countries & 19 & 19 & 19 & 19 & 19 & 19 & 19 & 19 \\
\hline Model & 27.8 & 32.79 & 7.5 & 7.49 & 34.25 & 49.41 & 158.91 & 73.25 \\
\hline$p$-value & 0.015 & 0.003 & 0.000 & 0.000 & 0.002 & 0.000 & 0.000 & 0.000 \\
\hline Hausman & 7.53 & 8.41 & 45.25 & 42.26 & & & & \\
\hline$p$-value & 0.8727 & 0.0777 & 0.000 & 0.000 & & & & \\
\hline
\end{tabular}

Note. For the description of the variables see Table 1. In Italics are reported the p-values of the tests. Superscripts $* * *$, ** and * denote statistical significance at the 1,5 and 10 percent level, respectively. Constant and time effects always included but not reported.

Across Table 5 columns, the org parameter sign is consistently positive when higher levels of the dependent variable signal higher efficiency (columns 1 and 5) and negative when lower levels of the dependent variable correspond to higher efficiency (all other columns). However, the parameter of interest is significant only in two instances: when estimating a Random Effects model with dependent variable EE_i, and when adopting a Tobit model for the EE_o_1 dependent variable. The same pattern holds true when adopting the Tobit estimator to perform several robustness checks, which are summarized in what follows, omitted to save on space and accessible on request. First, results are confirmed when changing the model specification, for instance adding the square of the GDP regressor, or changing the measure of education (secondary education pupils on population) or adding a measure of openness (exports plus imports as a share of GDP), to account for the potential influence of international trade on environmental efficiency (Taskim \& Zaim, 2001), or including a measure of control of corruption (WGI database), to gauge the hypothesis that bribery or other inducement practices to carry out businesses may affect productive and environmental efficiency (as well as the propensity to convert to organic management).

Furthermore, results are substantially unaltered when changing the type of frontier adopted. The environmental measures so far presented are based on a sequential frontier, i.e. on the assumption that the production possibility set can expand each year and no technological regress can occur. Therefore, the sequential frontier assumes as 
benchmark for each observation in a given year all other observations in the same year and the observations in the previous years. However, when using panel data, it is possible to define other two kinds of frontiers (Riccardi et al., 2012): intertemporal and contemporaneous. While to build the first one all observations are pooled together, the second one compares only observations of the same year. Table 5 results are confirmed when computing intertemporal frontiers (Note 13).

\section{Conclusions}

Climate change has inevitably drawn attention to the problem of greenhouse gas emissions in the atmosphere, and led to a call for appropriate policies to obviate or at least mitigate the consequences.

One important issue in the policy debate is the role that should be played by the agriculture sector in reducing the emissions blamed for rising global temperatures. Indeed, agriculture can contribute to both mitigation and sequestration of greenhouse gases. The scientific literature, however, is by no means of one mind on the extent to which this contribution is dependent on particular farming practices. In particular, the role that organic farming could play in reducing greenhouse gases is open to debate, the empirical evidence on this theme being scarce and based on samples of microeconomic data.

The purpose of this paper is to investigate the relationship between organic farming and greenhouse gas emissions by taking a macro perspective, and carrying out a two-fold analysis. First, the EKC approach is adopted to explore the influence of organic farming on per capita direct emissions. Secondly, total GHG emissions from the agricultural sector are considered as outputs of the agricultural production process and the impact of organic agriculture is evaluated on DEA measures of environmental efficiency.

According to the results obtained, whilst the share of agricultural land converted to organic farm management tends to be negatively associated with per capita emissions from agriculture, the relationship between the said share and certain measures of environmental efficiency is mostly not significant. It is important, nevertheless, to emphasize that further empirical research is called for to corroborate the present findings, as the analysis would have certainly benefited from the availability of longer time spans.

Bearing in mind this caveat, the empirical evidence here presented seems supporting the position according to that organic production practices could represent a tool to mitigate the climate change problem. However, organic farming appears weakly associated to gains in the environmental efficiency of the agricultural sector (the capacity to increase production, minimizing emissions), reinforcing the belief that this type of agriculture could be not sustainable where agriculture faces the huge challenge of feeding a growing population. Indeed, the debate on the crop yield gap between organic and conventional agriculture is still open (De Ponti et al., 2012). From a sceptical view, organic farming cannot produce the yields needed by the growing world population (Connor, 2008). On the other hand, some studies show that organic agriculture can increase productivity in developing countries (Badgley et al., 2007), and could provide cultivations more adaptable to arid soils and climate "turmoil", while at the same time reducing GHG emissions (FAO, 2002).

Finally, according to the Rodale Institute (2014) regenerative agriculture practices could represent the solution to the climate change problem, as soil carbon sinks could sequester all of our current global $\mathrm{CO} 2$ emissions. Ideally, future research should take into account the sequestration potential of organically managed soils as well as other related indirect benefits, deriving from the ban of fertilizers and pesticides and the withholding of certification for products grown on recently cleared or altered primary ecosystems, imposed by IFOAM standards.

\section{Acknowledgments}

I warmly thank an anonymous referee and the Editor of the journal for their comments and suggestions which helped to improve the paper. The usual disclaimers apply.

\section{References}

Aigner, D., Lovell, C. A., \& Schmidt, P. (1977). Formulation and Estimation of Stochastic Frontier Production Function Models. Journal of Econometrics, 6, 21-37. http://dx.doi.org/10.1016/0304-4076(77)90052-5

Badgley, C., Moghtader, J., Quintero, E., Zakem, E., Chappell, M., Avilés-Vázquez, K., Samulon, A., \& Perfecto, I. (2007). Organic agriculture and the global food supply. Renewable Agriculture and Food Systems, 22, 86-108. http://dx.doi.org/10.1017/S1742170507001640

Banker, R. D., \& Natarajan, R. (2008). Evaluating contextual variables affecting productivity using data envelopment analysis. Operations Research, 56, 48-58. http://dx.doi.org/10.1287/opre.1070.0460

Barrett, S., \& Graddy, K. (2000). Freedom, growth, and the environment. Environment and Development Economics, 4, 433-456. http://dx.doi.org/10.1017/S1355770X00000267 
Birdsall, N., \& Wheeler, D. (1993). Trade policy and industrial pollution in Latin America: Where are the pollution havens? Journal of Environment and Development, 2, 137-149. http://dx.doi.org/10.1177/107049659300200107

Blundell, R., \& Bond, S. (1998). Initial conditions and moment restrictions in dynamic panel data models. Journal of Econometrics, 87, 115-143. http://dx.doi.org/10.1016/S0304-4076(98)00009-8

Breitung, J. (2015). The Analysis of Macroeconomic Panel Data. In B. Baltagi (Ed.)., Panel Data (Chapter 15). Oxford Handbooks.

Casu, B., Girardone, C., \& Molyneux, P. (2004). Productivity change in European banking: A comparison of parametric and non-parametric approaches. Journal of Banking and Finance, 28, 2521-2540. http://dx.doi.org/10.1016/j.jbankfin.2003.10.014

Charnes, A., Cooper, W. W., \& Rhodes, E. (1978). Measuring the Efficiency of Decision-Making Units. European Journal of Operational Research, 2, 429-444. http://dx.doi.org/10.1016/0377-2217(78)90138-8

Chung, Y., Färe, R., \& Grosskopf, S. (1997). Productivity and undesirable outputs: A directional distance function approach. Journal of Environmental Management , 51, 229-240. http://dx.doi.org/10.1006/jema.1997.0146

Cole, M. A. (2003). Development, trade, and the environment: How robust is the Environmental Kuznets Curve? Environment and Development Economics, 8, 557-580. http://dx.doi.org/10.1017/S1355770X0300305

Cole, M. A., Rayner, A. J., \& Bates, J. M. (1997). The environmental Kuznets curve: An empirical analysis. Environment and Development Economics, 2, 401-416. http://dx.doi.org/10.1017/S1355770X97000211

Connor, D. J. (2008). Organic agriculture cannot feed the world. Field Crops Research, 106, 187-190. http://dx.doi.org/10.1016/j.fcr.2007.11.010

Coondoo, D., \& Dinda, S. (2002). Causality between income and emission: A country group-specific econometric analysis. Ecological Economics, 40, 351-367. http://dx.doi.org/10.1016/S0921-8009(01)00280-4

Cummins, J. D., \& Zi, H. (1998). Comparison of frontier efficiency methods: An application to the U.S., life insurance industry. Journal of Productivity Analysis, 10, 131-152. http://dx.doi.org/10.1023/A:1026402922367

Dalgaard, T., Halberg, N., \& Porter, J. (2001). A model for fossil energy use in Danish agriculture used to compare organic and conventional farming. Agricultural Ecosystem and Environment, 87, 51-65. http://dx.doi.org/10.1016/S0167-8809(00)00297-8

De Ponti, T., Rijk, B., \& Van Ittersum, M. (2012). The crop yield gap between organic and conventional agriculture. Agricultural Systems, 108, 1-9. http://dx.doi.org/10.1016/j.agsy.2011.12.004

Dinda, S. (2004). Environmental Kuznets Curve Hypothesis: A Survey. Ecological Economics, 49, 431-455. http://dx.doi.org/10.1016/j.ecolecon.2004.02.011

Elling, M., \& Luhnen, M. (2010). Efficiency in the international insurance industry: A cross-country comparison. Journal of Banking and Finance, 34, 1497-1509. http://dx.doi.org/10.1016/j.jbankfin.2009.08.026

FAO. (2002). Organic agriculture, environment and food security. In N. Scialabba, \& C. Hattam (Eds.), Environment and Natural Resources (Series 4). FAO, Rome.

Farrell, M. J. (1957). The measurement of productive efficiency. Journal of the Royal Statistical Society, 12, 254-281. http://dx.doi.org/10.2307/2343100

Flessa, H., Ruser, R., Dorsch, P., Kamp, T., Jimenez, M., Munch, J. C., \& Beese, F. (2002). Integrated evaluation of greenhouse gas emissions $(\mathrm{CO} 2, \mathrm{CH} 4, \mathrm{~N} 2 \mathrm{O})$ from two farming systems in southern Germany. Agricultural Ecosystem and Environment, 91, 175-189. http://dx.doi.org/10.1016/S0167-8809(01)00234-1

Färe, R., Grosskopf, S., \& Pasurka, C. A. (2003). Estimating Pollution Abatement Costs: A Comparison of "Stated" and "Revealed" approaches. Working Paper Oregon State University. http://dx.doi.org/10.2139/ssrn.358700

Galeotti, M., Lanza, A., \& Pauli, F. (2006). Reassessing the environmental Kuznets curve for CO2 emissions: A robustness exercise. Ecological Economics, 57, 152-163. http://dx.doi.org/10.1016/j.ecolecon.2005.03.031

Grossman, G. M., \& Krueger, A. B. (1995). Economic growth and the environment. Quarterly Journal of Economics, 110, 352-377. http://dx.doi.org/10.2307/2118443

Holtz-Eakin, D., \& Selden, T. M. (1995). Stoking the fires. CO2 emissions and economic growth. Journal of Public Economics, 57, 85-101. http://dx.doi.org/10.1016/0047-2727(94)01449-X 
Im, K. S., Pesaran, M. H., \& Shin, Y. (2003). Testing for unit roots in heterogeneous panels. Journal of Econometrics, 115, 53-74. http://dx.doi.org/10.1016/S0304-4076(03)00092-7

Iwata, H., Okada, K., \& Samreth, S. (2010). Empirical study on the environmental Kuznets curve for CO2in France: The role of nuclear energy, Energy Policy, 38, 4057-4063. http://dx.doi.org/10.1016/j.enpol.2010.03.031

Iwata, H., Okada, K., \& Samreth, S. (2011). A note on the environmental Kuznets curve for CO2: A pooled mean group approach. Applied Energy, 88, 1986-1996. http://dx.doi.org/10.1016/j.apenergy.2010.11.005

Johnson, A. L., \& Kuosmanen, T. (2012). One-stage and two-stage DEA estimation of the effects of contextual variables. European Journal of Operational Research, 220, 559-570. http://dx.doi.org/10.1016/j.ejor.2012.01.023

Kearsley, A., \& Riddel, M. (2010). A further inquiry into the Pollution Haven Hypothesis and the Environmental Kuznets Curve. Ecological Economics, 69, 905-919. http://dx.doi.org/10.1016/j.ecolecon.2009.11.014

Kim, D. H., Lin, S. C., \& Suen, Y. B. (2010). Dynamic effects of trade openness on financial development. Economic Modelling, 27, 254-261. http://dx.doi.org/10.1016/j.econmod.2009.09.005

Lampkin, N. (1997). Organic Livestock Production and Agricultural Sustainability. In: Resource use in Organic Farming Proceedings of the Third ENOF Workshop (Ancona 5-6 June 1997, pp. 321-330).

Lee, C. C., Chiu, Y. B., \& Sun, C. H. (2010). The environmental Kuznets curve hypothesis for water pollution: Do regions matter? Energy Policy, 38, 12-23. http://dx.doi.org/10.1016/j.enpol.2009.05.004

Leitão, A. (2010). Corruption and the environmental Kuznets Curve: Empirical evidence for sulphur. Ecological Economics, 69, 2191-2201. http://dx.doi.org/10.1016/j.ecolecon.2010.06.004

Leitão, N. C., \& Shahbaz, M. (2013). Carbon dioxide emissions, urbanization and globalization: A dynamic panel data. The Economic Research Guardian, 3, 22-32.

Levin, A., Lin, C. F., \& Chu, C. S. J. (2002). Unit root tests in panel data: Asymptotic and finite-sample properties. Journal of Econometrics, 108, 1-24. http://dx.doi.org/10.1016/S0304-4076(01)00098-7

Lundström, S. (1997). Bör vi dricka ekologisk mjölk - An Economical Comparision of Conventional and Organic Milk Production. In S. Lundström (Ed.), Examination certificate (p. 143).

Martínez-Zarzoso, I., \& Bengochea-Morancho, A. (2004). Pooled mean group estimation of an environmental Kuznets curve for CO2. Economic Letters, 82, 121-6. http://dx.doi.org/10.1016/j.econlet.2003.07.008

Mazzanti, M., Montini, A., \& Zoboli, R. (2008). Municipal Waste Generation and Socioeconomic Drivers. Evidence From Comparing Northern and Southern Italy. The Journal of Environment and Development, 17, 51-69. http://dx.doi.org/10.1177/1070496507312575

Orubu, C., \& Omotor, D. G. (2011). Environmental quality and economic growth: Searching for environmental Kuznets curves for air and water pollutants in Africa. Energy Policy, 39, 4178-4188. http://dx.doi.org/10.1016/j.enpol.2011.04.025

Panayotou, T. (1993). Empirical Tests and Policy Analysis of Environmental Degradation at Different Stages of Economic Development. Working Paper WP238, Technology and Employment Programme, International Labour Office, Geneva.

Perman, R., \& Stern, D. I. (2003). Evidence from panel unit root and cointegration tests that the environmental Kuznets curve does not exist. Australian Journal of Agricultural and Resource Economics, 47, 325-347. http://dx.doi.org/10.1111/1467-8489.00216

Pesaran, M. H., \& Smith, R. (1995). Estimating long-run relationships from dynamic heterogeneous panels. Journal of Econometrics, 68, 621-634. http://dx.doi.org/10.1016/0304-4076(94)01644-F

Pesaran, M. H., Shin, Y., \& Smith, R. (1999). Pooled mean group estimation of dynamic heterogeneous panels. Journal of the American Statistical Association, 94, 621-634. http://dx.doi.org/10.1080/01621459.1999.10474156

Refsgaard, K., Halbergb, N., \& Kristensenb, E. (1998). Energy Utilization in Crop and Dairy Production in Organic and Conventional Livestock Production Systems. Agricultural Systems, 5, 599-630. http://dx.doi.org/10.1016/S0308-521X(98)00004-3

Reganold, J. P., Palmer, A. S., Lockhart, J. C., \& MacGregor, A. N. (1993). Soil quality and financial performance of bio-dynamic and conventional farms in New Zealand. Science, 260, 344-349. http://dx.doi.org/10.1126/science.260.5106.344 
Riccardi, R., Oggioni, G., \& Toninelli, R. (2012). Efficiency analysis of world cement industry in presence of undesirable output: Application of data envelopment analysis and directional distance function. Energy Policy, 44, 140-152. http://dx.doi.org/10.1016/j.enpol.2012.01.030

Rochette, P., Angers, D. A., Chantigny, M. H., \& Bertrand, N. (2008). Nitrous oxide emissions respond differently to no-till in loam and heavy clay soil. Soil Science Society of America Journal, 72, 1363-1369. http://dx.doi.org/10.2136/sssaj2007.0371

Rodale Institute (2014). Regenerative Organic Agriculture and Climate Change. A Down-to-Earth Solution to Global Warming. Kutztown, PA, USA.

Scialabba, N. (2000). Factors influencing organic agriculture policies with a focus on developing countries. IFOAM 2000 Scientific Conference, Basel, Switzerland.

Scialabba, N., \& Lindenlauf, M. (2010). Organic agriculture and climate change. Renewable Agriculture and Food Systems, 25, 158-169. http://dx.doi.org/10.1017/S1742170510000116

Stern, D. I. (2004). The Rise and Fall of the Environmental Kuznets Curve. World Development, 32, 1419-1439. http://dx.doi.org/10.1016/j.worlddev.2004.03.004

Stern, D. I., Common, M. S., \& Barbier, E. B. (1996). Economic growth and environmental degradation: The Environmental Kuznets Curve and sustainable development. World Development, 24, 1151-1160. http://dx.doi.org/10.1016/0305-750X(96)00032-0

Stolze M., Piorr, A., Häring, A., \& Dabbert, S. (2000). The Environmental Impacts of Organic Farming in Europe. Economics and Policy, 6. Stuttgart-Hohenheim.

Suri, V., \& Chapman, D. (1998). Economic growth, trade and the environment: Implications for the environmental Kuznets curve. Ecological Economics, 25, 195-208. http://dx.doi.org/10.1016/S0921-8009(97)00180-8

Taskin, F., \& Zaim, O. (2001). The role of international trade on environmental efficiency: A DEA approach, Economic Modelling, 18, 1-17. http://dx.doi.org/10.1016/S0264-9993(00)00025-0

Torras, M., \& Boyce, J. K. (1998). Income, inequality, and pollution: A reassessment of the environmental Kuznets Curve. Ecological Economics, 25, 147-160. http://dx.doi.org/10.1016/S0921-8009(97)00177-8

Unwin, R., Bell, B., Sheperd, M., Webb, J., Keatinge, R., \& Bailey, S. (1995). The Effects of Organic Farming Systems on Aspects of the Environment. Agricultural Resources Policy Division of the Ministry of Agriculture, Fisheries and Food, HMSO; London.

Wagner, M. (2008). The carbon Kuznets curve: A cloudy picture emitted by bad econometrics? Resources and Energy Economics, 30, 388-408. http://dx.doi.org/10.1016/j.reseneeco.2007.11.001

Wagner, M. (2014). The Environmental Kuznets Curve, Cointegration and Nonlinearity. Journal of Applied Econometrics. http://dx.doi.org/10.1002/jae.2421

Watanabe, M., \& Tanaka, K. (2007). Efficiency analysis of Chinese industry: A directional distance function approach. Energy Policy, 35, 6323-6331. http://dx.doi.org/10.1016/j.enpol.2007.07.013

Welsch, H. (2004). Corruption, growth and the environment: A cross-country analysis. Environment and Development Economics, 9, 663-693. http://dx.doi.org/10.1017/S1355770X04001500

Wood, R., Lenzen, M., Dey, C., \& Lundie, S. (2006). A comparative study of some environmental impacts of conventional and organic farming in Australia. Agricultural Systems, 89, 324-348. http://dx.doi.org/10.1016/j.agsy.2005.09.007

Wu, Y. (2010). Regional Environmental Performance and its Determinants in China. China and World Economy, 18, 73-89. http://dx.doi.org/10.1111/j.1749-124X.2010.01197.x

\section{Notes}

Note 1. Unit root tests are not performed for the variables entering the second stage estimations based on DEA efficiency measures, as the relative estimation samples will be more limited, the time spans ranging from 1 to 9 .

Note 2. However, several authors have warned against considering policies promoting growth as substitutes for environmental policy. Indeed, the evidence on the ECK hypothesis is mixed and some authors have challenged its fundamental notion both on theoretical (Stern et al.,1996) and methodological grounds (Stern et al., 1996; Coondoo \& Dinda, 2002; Perman \& Stern, 2003; Wagner, 2008). Dinda (2004) and Stern (2004) provide ample reviews of 
both critiques. In the following, econometric concerns will be described in more detail.

Note 3. According to the Pollution Haven Hypothesis, PHH (that is also compatible with the Heckscher-OhlinSamuelson model), pollution-intensive industries tend to move from developed countries with more stringent environmental regulations to developing nations representing "pollution havens" (Cole, 2003). As Kearsley and Riddel (2010) summarize, the evidence on the PHH is ambiguous. As far as OECD countries are concerned, Birdsall and Wheeler (1993) find that the tightening of environmental regulation in these countries seem followed by expansion of domestic pollution-intensive industries.

Note 4. According to Torras and Boyce (1998) the distribution of power within a society influences the environmental policies adopted, and thus pollution emissions. The variables employed by these authors as proxies of such a distribution (the GINI coefficient and the literacy rate) were not employed in this analysis as defined on a limited number of observations. A measure of secondary education will be employed instead.

Note 5. All models adopted share the basic equation (1) specification. In the FE/RE and the GMM-SYS cases, the error term is decomposed in two parts: $v_{i t}=\mu_{i}+\varepsilon_{i t}$, where the individual effect $\left(\mu_{i}\right)$ summarizes time-invariant unobserved country characteristics, and the second term $\left(\varepsilon_{i t}\right)$ captures idiosyncratic shocks to GHG emissions.

Note 6. As Kim et al. (2010) point out "Provided that there is a unique vector defining the long-run relationship among variables involved, with the lag order span d q suitably chosen, MG and PMG estimates of an ARDL regression yield consistent estimates of that vector, no matter whether the variables involved are I(1) or I(0)" (page 256).

Note 7. This choice is generally shared (e.g. Pesaran et al., 1999; Iwata et al., 2010; Kim et al., 2010) to allow for reasonably rich dynamics when the sample size implies limited degrees of freedom for the econometric analysis.

Note 8. As concerns the GMM results, the autocorrelation (AR1 and AR2) tests yield the expected diagnostics: they signal a first order correlation in the differenced residuals (at the $11 \%$ in the $\mathrm{CO} 2$ case), but no higher order autocorrelation. Further, the Hansen test does not reject the null hypothesis of validity of the over-identifying restrictions, even though - despite its limitation - the number of instruments remains high when compared to the number of observations, and this may imply little power of the Hansen test.

Note 9. The estimation samples reported by Table 3 are smaller than those displayed by Table 2, as the PMG approach needs that each cross-section unit (country) is observed on a reasonable long time span (T) to yield reliable results. In the panel here employed, the minimum T that is compatible with convergence is 12.

Note 10. Banker and Natarajan (2008) and Johnson and Kuosmanen (2012) show that this two-stage procedure is statistically consistent under different conditions, providing theoretical justification for its use. Further, Johnson and Kuosmanen (2012) show that the impact of finite sample bias of DEA reverberates into the second stage regression, and becomes significant if the explanatory variables of the second stage equation are correlated with the inputs entering the first stage linear programs. Since the latter correlation is low in the sample under study, the two-stage method that uses DEA in the first stage is adopted.

Note 11. The DEA approach is a linear programming-based methodology that, without imposing any a priori assumptions on the functional form of the frontier, provides non-parametric measures of efficiency relative to the sample employed. An alternative econometric approach is the stochastic frontier analysis (SFA), based on specific production functions generating absolute measures of efficiency (Aigner et al., 1977). According to several contributions, the two methodologies tend to yield consistent results (Cummins \& Zi, 1998; Casu et al., 2004; Elling \& Luhnen, 2010; Cummins \& Xie, 2013).

Note 12. The directional distance function encompasses also the hyperbolic graph efficiency measure, which allows both inputs and outputs to change by the same proportion, in opposite directions (see, for instance, Taskim \& Zaim, 2001).

Note 13. Contemporaneous frontiers are discarded as some years are characterized by a limited number of observations. 


\section{Appendix A}
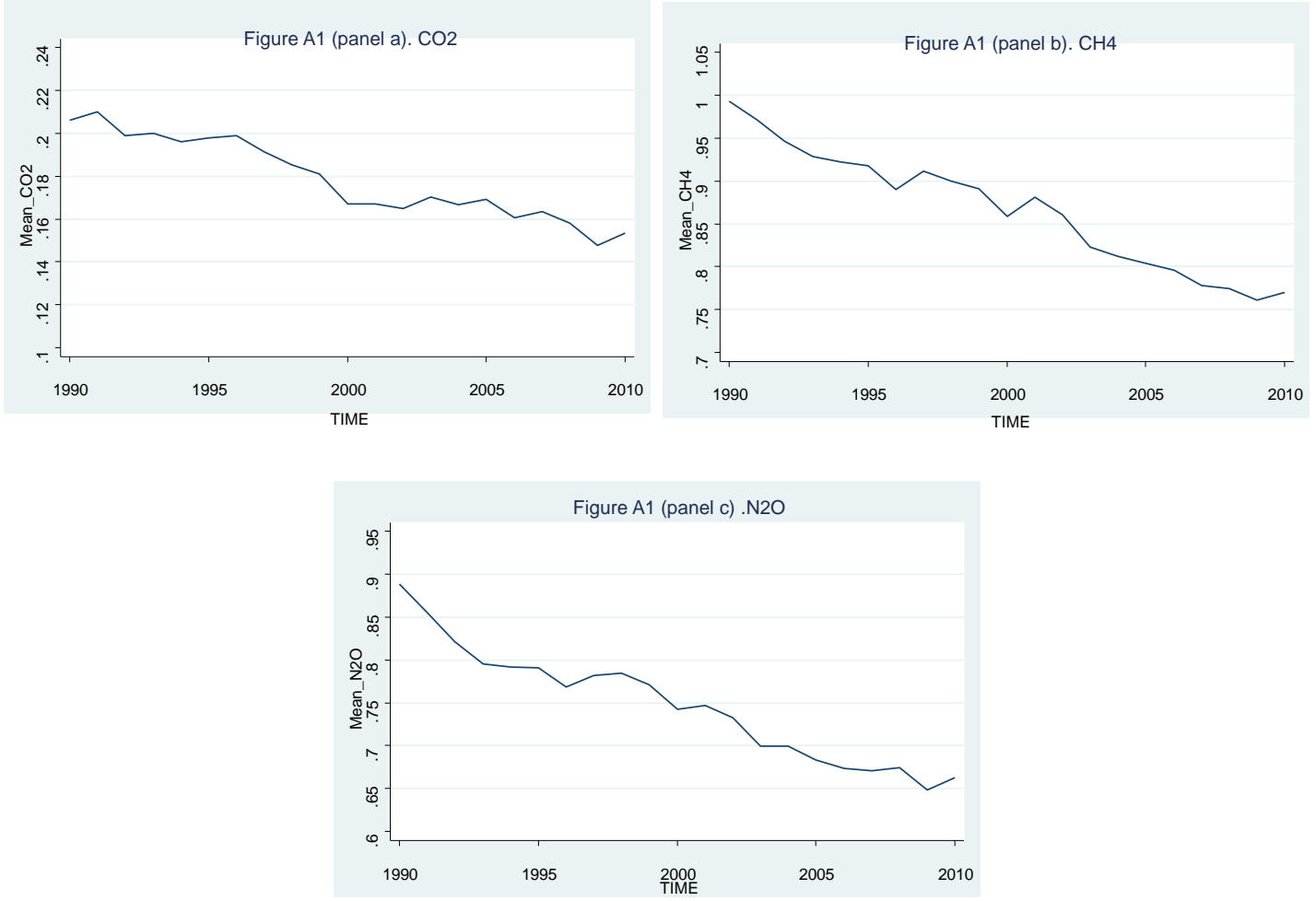

Figure A1. GHG emissions over time (mean values)

Table A1. Unit root tests

\begin{tabular}{lcccccc}
\hline & \multicolumn{3}{c}{ Without trend } & \multicolumn{3}{c}{ With trend } \\
\cline { 2 - 7 } CO2 & ADF & PP & IPS & ADF & PP & IPS \\
& 44.67 & 103.058 & -0.53 & 30.1 & 56.274 & -1.92 \\
CH4 & 0.862 & 0.000 & 0.299 & 0.998 & 0.465 & 0.027 \\
& 49.97 & 145.335 & -2.59 & 48.67 & 159.724 & -5.15 \\
N2O & 0.819 & 0.000 & 0.005 & 0.852 & 0.000 & 0.000 \\
& 37.22 & 185.066 & -4.326 & 58.457 & 180.115 & -1.134 \\
GDP & 0.991 & 0.000 & 0.000 & 0.532 & 0.000 & 0.128 \\
& 26.082 & 88.088 & 0.19 & 34.036 & 102.175 & -0.75 \\
OPEN & 1.000 & 0.011 & 0.575 & 0.997 & 0.001 & 0.227 \\
& 66.41 & 57.654 & -3.161 & 35.105 & 97.45 & -3.046 \\
O_SHARE & 0.266 & 0.562 & 0.001 & 0.996 & 0.002 & 0.001 \\
& 126.802 & 185.206 & -5.151 & 89.519 & 331.071 & -5.233 \\
& 0.000 & 0.000 & 0.000 & 0.001 & 0.000 & 0.000 \\
\hline
\end{tabular}

Note. PP stands for Phillips-Perron test; ADF for augmented Dickey-Fuller test; IPS for Im-Pesaran-Shin test. Ho: all panels contain unit roots. $\mathrm{P}$-values are reported in italics. 
Table A2. Robustness checks results

\begin{tabular}{|c|c|c|c|c|c|c|c|c|c|c|c|c|}
\hline & \multicolumn{3}{|c|}{ OLS } & \multicolumn{3}{|c|}{ PRAIS-W } & \multicolumn{3}{|c|}{ FE/RE } & \multicolumn{3}{|c|}{ GMM } \\
\hline & $\mathrm{CO2}$ & CH4 & N2O & $\mathrm{CO2}$ & CH4 & N2O & $\mathrm{CO} 2$ & CH4 & $\mathrm{N} 2 \mathrm{O}$ & $\mathrm{CO} 2$ & CH4 & $\mathrm{N} 2 \mathrm{O}$ \\
\hline \multirow[t]{2}{*}{ org } & $-0.110^{* * *}$ & $-0.256^{* * *}$ & $-0.136^{* * *}$ & -0.034 & $-0.081 * * *$ & $-0.042 * * *$ & 0.032 & -0.003 & $-0.015^{* * *}$ & $-0.099 *$ & $-0.014 * *$ & $-0.031^{* *}$ \\
\hline & 0.002 & 0.000 & 0.000 & 0.142 & 0.000 & 0.000 & 0.445 & 0.534 & 0.006 & 0.087 & 0.024 & 0.045 \\
\hline \multirow[t]{2}{*}{ gdp } & $7.133 * * *$ & $8.841^{* * * *}$ & $5.997 * * *$ & 3.702 & $2.048 * *$ & -1.052 & -1.974 & -0.48 & $0.860 * *$ & 2.402 & $0.902 * * *$ & 1.59 \\
\hline & 0.001 & 0.000 & 0.000 & 0.197 & 0.025 & 0.256 & 0.556 & 0.187 & 0.046 & 0.348 & 0.001 & 0.179 \\
\hline \multirow[t]{2}{*}{$\operatorname{gdp}^{2}$} & $-0.377 * * *$ & $-0.405^{* * *}$ & $-0.291 * * *$ & -0.201 & $-0.088^{*}$ & 0.046 & 0.141 & 0.014 & $-0.041^{*}$ & -0.118 & $-0.044 * * *$ & -0.079 \\
\hline & 0.001 & 0.000 & 0.000 & 0.170 & 0.052 & 0.316 & 0.391 & 0.419 & 0.051 & 0.352 & 0.002 & 0.187 \\
\hline \multirow[t]{2}{*}{ open } & $0.245^{* * *}$ & $0.319 * * *$ & $0.196 * * *$ & -0.172 & 0.03 & $-0.047^{*}$ & $-0.551^{*}$ & $-0.168^{* * *}$ & $-0.111 * * *$ & 0.14 & 0.022 & 0.059 \\
\hline & 0.002 & 0.000 & 0.001 & 0.140 & 0.309 & 0.096 & 0.051 & 0.000 & 0.002 & 0.242 & 0.275 & 0.160 \\
\hline \multirow[t]{2}{*}{ EC } & $0.341^{* *}$ & $0.166^{*}$ & $0.496^{* * * *}$ & 0.198 & $0.395^{* * *}$ & $0.311^{* * *}$ & $0.838^{* *}$ & $0.361 * * *$ & $0.359 * * *$ & -0.028 & 0.006 & 0.075 \\
\hline & 0.040 & 0.092 & 0.000 & 0.331 & 0.000 & 0.000 & 0.042 & 0.000 & 0.000 & 0.746 & 0.754 & 0.236 \\
\hline \multirow[t]{2}{*}{ EDU } & 0.102 & $1.751^{* * * *}$ & $1.329 * * *$ & -0.002 & $0.185 * *$ & -0.015 & 0.239 & $0.044^{*}$ & $0.097 * * *$ & -0.005 & 0.045 & $0.174 * * *$ \\
\hline & 0.743 & 0.000 & 0.000 & 0.989 & 0.020 & 0.810 & 0.306 & 0.095 & 0.002 & 0.961 & 0.200 & 0.009 \\
\hline \multirow[t]{2}{*}{ URB } & $0.736 * * *$ & $-1.447 * * *$ & $-0.851 * * *$ & $1.065^{* * *}$ & $-0.733 * * *$ & $0.633 * * *$ & 0.603 & -0.09 & $-1.662 * * *$ & -0.017 & -0.058 & -0.124 \\
\hline & 0.002 & 0.000 & 0.000 & 0.000 & 0.000 & 0.000 & 0.627 & 0.520 & 0.000 & 0.932 & 0.159 & 0.287 \\
\hline \multirow[t]{2}{*}{ trend } & -0.006 & $0.028 * * *$ & 0.004 & -0.004 & 0.003 & $-0.007 * *$ & $-0.045^{* * *}$ & $-0.004 * * *$ & $-0.006^{* * *}$ & 0.01 & $0.002 *$ & 0.002 \\
\hline & 0.473 & 0.000 & 0.416 & 0.674 & 0.306 & 0.014 & 0.000 & 0.002 & 0.000 & 0.119 & 0.076 & 0.367 \\
\hline \multirow[t]{2}{*}{ L.Dep. Var. } & & & & & & & & & & $1.012 * * *$ & $0.962 * * *$ & $0.856 * * *$ \\
\hline & & & & & & & & & & 0.000 & 0.000 & 0.000 \\
\hline Obs & 367 & 383 & 383 & 367 & 383 & 383 & 367 & 383 & 383 & 356 & 371 & 371 \\
\hline Countries & 28 & 30 & 30 & 28 & 30 & 30 & 28 & 30 & 30 & 28 & 30 & 30 \\
\hline F (or Wald) test & t 11.37 & 25.65 & 34.75 & 67.88 & 547.19 & 433.38 & 12.32 & 1076.6 & 1080.87 & 332.09 & 933.07 & 117 \\
\hline$p$-value & 0.000 & 0.000 & 0.000 & 0.000 & 0.000 & 0.000 & 0.000 & 0.000 & 0.000 & 0.000 & 0.000 & 0.000 \\
\hline AR1 & & & & & & & & & & -2.08 & -2.76 & -3.09 \\
\hline$p$-value & & & & & & & & & & 0.037 & 0.006 & 0.002 \\
\hline AR2 & & & & & & & & & & 1.77 & 0.91 & 0.97 \\
\hline$p$-value & & & & & & & & & & 0.076 & 0.362 & 0.333 \\
\hline Hansen & & & & & & & & & & 21.8 & 23.37 & 26.01 \\
\hline$p$-value & & & & & & & & & & 1 & 1 & 1 \\
\hline
\end{tabular}

Note. EC is per capita national energy consumption; EDU is the number of secondary education pupils, scaled by population; URB is urban population to total population. For the description of the other variables see Table 2. All variables are in logarithmic form. In Italics are reported the p-values of the tests. Superscripts ***,** and * denote statistical significance at the 1, 5 and 10 percent level, respectively. Constant always included but not reported. AR1 and AR2 stand for Arellano-Bond test for AR(1) in first differences and Arellano-Bond test for AR(2) in first differences, respectively. For the Hansen test, the null hypothesis is the validity of the over-identifying restrictions.

\section{Copyrights}

Copyright for this article is retained by the author(s), with first publication rights granted to the journal.

This is an open-access article distributed under the terms and conditions of the Creative Commons Attribution license (http://creativecommons.org/licenses/by/4.0/). 